\title{
Faith-based organisations between service delivery and social change in contemporary China: The experience of Amity Foundation
}

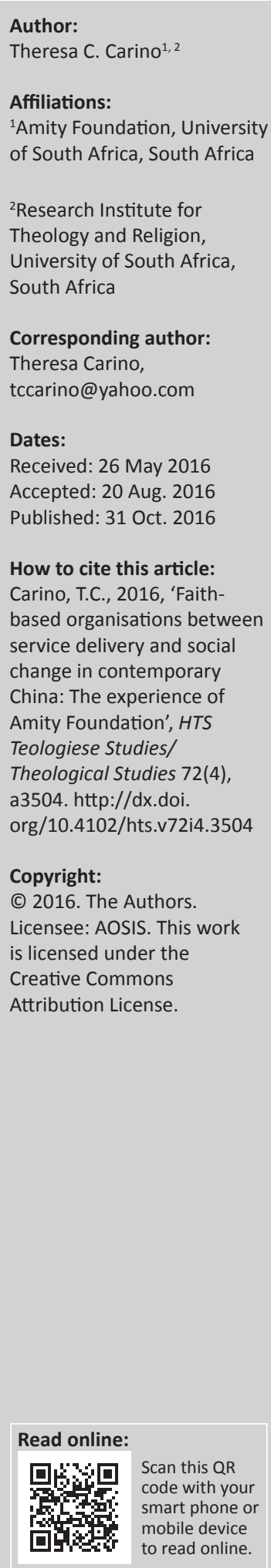

China has undergone a profound paradigm shift in its approach to economic development since its policy of 'opening and reform' was first implemented in 1978. It has shifted rapidly from a centrally planned economy to a market-oriented one, speeding up its economic development through foreign investment, a more open market, access to advanced technologies and management experience. It is notable that its economic growth, marked by annual doubledigit rises in GDP over two decades, has lifted more than 400 million people out of extreme poverty. Today, the number of Chinese billionaires has ballooned, but so has the rich-poor gap. China's 'development' has to address this urgent issue.

This article examines, based on the experience of Amity Foundation, one of China's largest faith-based organisations (FBOs), how religious organisations are being harnessed by the state to redress the wealth gap arising from 'development'. The process of social engagement has empowered FBOs, made their presence more accepted and appreciated in Chinese society and contributed to the creation of more social and political space for a nascent civil society. The author argues that FBOs must provide visible, viable and replicable alternatives in their social practices that are firmly rooted in their faith, if they are to make any sustainable impact on the development debate.

\section{Introduction}

The 'Four Modernisations' in agriculture, industry, national defense and science and technology were adopted as a means of rejuvenating China's economy in 1978 following the death of Mao Zedong. Goals were first set forth by the then Chinese Vice-Premier, Zhou Enlai, in 1963, and enacted by Deng Xiaoping, starting in 1978 (Tisdell 2008). It was a reaction to the Mao-inspired Cultural Revolution ${ }^{1}$ (1966-1976) that had emphasised the intensification of collectivisation and labour-intensive agriculture. After Mao's death in 1976 more moderate Chinese leaders such as Deng Xiaoping adopted policies that allowed foreign direct investment in special economic zones in southern parts of China. The collectivist system in agriculture was dismantled and private enterprise in agriculture and industry began to be encouraged. The value of higher education was recognised, and this was accompanied by the upgrading of science and technology as a means of modernising China's economic system (see Vogel 2011).

Since then, China has shifted rapidly from a centrally planned economy towards a marketoriented one, in the process allowing the entry of large-scale multilateral funding agencies including the World Bank and the Asian Development Bank (Economist 2011). China's entry into the World Trade Organisation (WTO) in 2002 was a monumental step in opening up China's economy and transforming China's international trade (Economist 2011; Panitchpakdi \& Clifford 2002). By participating in export-led growth, China was able to speed up its economic development through foreign investments, a more open market, access to advanced technologies and management experience (Economist 2011). It is notable that its economic growth, marked by annual double-digit rises in GDP over two decades, has lifted more than 400 million people out of extreme poverty (World Bank 2016). Nevertheless, at the end of 2014, China still had 70 million people in the countryside living below the nation's poverty line of 2300 yuan (about US\$354) in 1.In 1966, Mao Zedong mobilised Chinese youth, known as 'Red Guards', to launch a movement opposing Chinese Communist Party
leaders who had disagreed with his efforts to hasten the establishment of large communes in China. The Cultural Revolution, as the
movement was called, led to the widespread persecution of officials, intellectuals, religious figures and those considered to be of
bourgeois origins. It marked a turbulent and often violent decade in which higher institutions of learning were closed, religious practices banned and cultural traditions and relics destroyed (see Wickeri 2007).

Note: This article forms part of the special collection on 'Engaging development: Contributions to a critical theological and religious debate' in HTS Teologiese Studies/Theological Studies Volume 72, Issue 4, 2016. 
annual income (Xinhua News 2016a). With rapid urbanisation, poverty is no longer confined to rural areas and the rich-poor gap is one of the widest in the world (Kaiman 2014).

This article will explore how religious organisations are being harnessed by the state to redress the wealth gap and 'unintended consequences' arising from 'development'. For faith-inspired non-governmental organisations (NGOs) or FBOs,${ }^{2}$ 'engaging development' constitutes a necessity rather than an option. The process of engagement has empowered religious organisations, made their presence more accepted and appreciated in Chinese society and contributed to the creation of more social and political space for a nascent civil society. There are certainly limits and political constraints on what religious organisations can do within the Chinese context. However, the experiences of FBOs in China confirm that they must provide visible, viable and replicable alternatives in their social practices that are firmly rooted in their faith, if they are to make any impact.

For many Christians, especially those in the ecumenical movement who are engaged in poverty reduction, development is not simply economic growth or the accumulation of material wealth.

The reformed tradition and the Protestant faith profess the primacy of human dignity as human beings are created in God's image imbued with inviolable dignity. Poverty and underdevelopment devalue humans and violates God's created order. (Ocampo 2014:179)

Development, therefore, has spiritual, social, economic and political dimensions that are intertwined. There is no single adequate definition of development, but Philip Wickeri's (2010) definition of 'social development as the promotion of human flourishing through social transformation, economic growth, ecological sensitivity and political participation' provides us with a working definition. An important aspect of development is the eradication of extreme poverty and wealth disparity.

In China, while it is true that 400 million have been lifted out of poverty, new challenges have emerged including the growing rich-poor gap, massive and rapid urbanisation that has torn apart families and undermined communities in rural areas, and high rates of air, water and soil pollution from industrial waste. ${ }^{3}$ In responding to some of the social problems and dislocations that have arisen from rapid change, FBOs have made considerable contributions to development over the last two decades, and these should be appreciated given the socio-political context in which

2.Some authors have used "faith-inspired NGOs' to describe organisations with a religious background and origins but are not necessarily run by religious institutions. In China, for instance, the Amity Foundation was initiated by Christian leaders and is inspired by religious values but is run independently from the church. The term 'faithbased organisation' (FBO) often refers to the social development arm of a religious institution. In China, this would include the social service department of the Chin Christian Council or the Social Service Centers of Catholic churches. In this article Christian Councilor however, the term FBO will be used to broadly embrace social development organisations run either by churches or Christians as well as faith-inspired NGOs. It decheshan jigou) would roughly be translated as 'religious philanthropic organisations'.

3.In rural areas, for instance, water pollution has been blamed for deaths due to stomach and liver cancer (Ebenstein 2008). they operate. In demonstrating how FBOs have made an impact, this article has relied heavily on the experiences of the Amity Foundation, a Chinese FBO established in 1985 by Chinese Protestant leaders such as Bishop K.H. Ting and Dr Han Wenzao (Wickeri 2007).

\section{The religious context in China}

In China, the issue of 'religion' is still a sensitive one. It should be noted at the outset that China's policy towards religion ${ }^{4}$ (since the establishment of the People's Republic of China in 1949) has been strongly influenced both by the official interpretation of Marxism by the Chinese Communist Party as well as China's centuries-old tradition of subordinating religion to the state. According to a leading religious scholar, Xinping Zhuo, (2014), 'The only relationship between State and religion that ever existed in China was the primacy of the State and the subordination of religion'. It was never the other way around. During the Cultural Revolution, religion was simply regarded as an 'opiate of the people' ${ }^{5}$ and was strongly attacked. Religious sites were closed down, religious practices banned and religious leaders were imprisoned or sent to labour in farms and factories (Liu 2005). From 1978 onwards, along with the liberalisation of economic policies, there have been higher levels of religious tolerance among officials. During the 1980s and 1990s, the five major religions in China (Christianity, Catholicism, Islam, Buddhism and Taoism $)^{6}$ focused on the restoration of places of worship. These two decades also saw a rapid resurgence in religious belief that cut across all religions.

Today, China has the world's largest Buddhist population, rapidly growing Catholic and Protestant congregations, expanding Muslim communities and active Daoist temples (Ashiwa \& Wank 2009). According to official statistics, in 1997, there were more than 13000 Buddhist temples, 1500 Daoist temples, 30000 mosques, 4000 Catholic churches and 12000 Protestant churches in China (Ashiwa \& Wank 2009). In October 2012, a press release by the State Administration for Religious Affairs (SARA) indicated that there were nearly 5500 religious groups, about 130000 sites for religious activities, 360000 clergy and over 100 million religious believers in China (Ashiwa \& Wank 2009).

Statistics published by a Catholic research institution show that by the end of 2009, a total of 422 charitable and cultural Catholic organisations existed in China, including more than 220 clinics, 81 nursing homes, 44 kindergartens, 22 infant hospitals or rehabilitation centres and 35 regional or parish social service agencies (Zuo \& Bai 2012). Large, highly specialised institutions include Jinde Charities (Catholic) of Hebei Province, Shengjing Ren'ai (Buddhist) of Liaoning

4.In this article, religion will simply refer to institutionalised religion in China, particularly the five major religions.

5.Karl Marx had said that religion was the opium of the people while Lenin had taken it further by describing religion as opium for the people (see Wickeri 2007). Religion was thus regarded as an instrument for pacifying the oppressed in a class society and associated with backwardness and superstition. This view continues to persist among some officials although there are contending views.

6.In China, Protestant Christianity and Catholicism are considered as different religions. This was mainly due to the fact that western missionaries used different terms for 'God' in Chinese. 
Province and the Xi'an Diocese Social Service Center (Catholic) of Shaanxi Province (Zuo \& Bai 2012).

In 22 March 2012 a new government document regulating the social welfare activities of the religions was jointly released by the SARA and the United Front Department of the Communist Party of China and various state ministries. It was called the 'Views on Encouraging Religious Groups to Carry Out Charitable Activities and the Regulation of the Same' (China Zentrum 2012).

The new regulation in 2012 defined the forms, principles and preferential measures available for religious groups to carry out 'charitable' activities. Under the principles of 'active support, equal treatment and lawful administration', the new regulation encouraged active involvement from religious organisations in disaster and poverty relief; care of the disabled, seniors and children; providing education opportunities and medical care; environmental protection; and public facility construction. Tariff waivers and tax reductions would be allowed when faith-based charitable groups receive donations from outside China and use them directly for charitable causes such as poverty alleviation (Union of Catholic Asian News [UCAN] 2012).

In the last few years, authorities have been more forthcoming in acknowledging the contributions of religious organisations. In a SARA press release it was mentioned that:

They [religious organisations] have gradually transformed from simply meeting material needs of service targets to paying full attention to psychological, spiritual and social needs; from a scattered, spontaneous and monotonous state to a systematic, organised and diversified situation. (UCAN 2012)

The upgrading of social services provided by FBOs reflected not only a more conducive socio-political environment towards religion but also an expansion in their capacity to engage in social development work. The growth of congregations and worshippers had meant that religious institutions were able to gather more resources that could be used for charitable purposes. With the deepening of their social involvement, FBOs had become more professional and some had begun to see social engagement as a process of social change and transformation (Wang 2014). ${ }^{7}$

\section{Economic growth and poverty reduction}

Sustainable development has been defined in many ways, but the most frequently quoted definition is from Our Common Future, also known as the Brundtland Report:

Sustainable development is development that meets the needs of the present without compromising the ability of future generations to meet their own needs. It contains within it two key concepts: the concept of needs, in particular the essential needs of the world's poor, to which overriding priority should be

7.In her article 'The Catholic Social Service Center of Xi'an Diocese: Stages in Development', Wang Ting explains the evolution of the work of the Catholic Social the advocacy of 'participatory development' (Wang 2014). given; and the idea of limitations imposed by the state of technology and social organisation on the environment's ability to meet present and future needs. (World Commission on Environment and Development (WCED) 1987)

The term 'sustainable development' is now widely used, and there is more or less a 'global consensus' over what it means to be 'developed' especially for nations participating (nominally or seriously) in the United Nations Development Programme (UNDP)-led drive targeting the Social Development Goals (SDGs) for 2030. The advantage of these goals is that they have become acceptable indicators of 'development' by countries that span both market and hybrid political and economic systems. While 'development' with its complex dimensions may not be fully circumscribed by the Millenium Development Goals (MDGs) 2015 or SDGs 2030, these still serve as useful guideposts for societies and set global benchmarks for governments in the continuous assessment and debate on policies and national development plans. They also provide NGOs leverage and a platform in holding governments accountable. Even in a one-party authoritarian state such as China, the government is sensitive to public opinion and realises that its political legitimacy derives from its effective and efficient delivery of public goods. China is eager to demonstrate that Chinese 'socialism with market characteristics' while integrating China's economy more closely with the global market economy, can also work effectively in reducing poverty levels. Hu Jintao (2007), in reporting to the 17th Party Congress, outlined China's remarkable achievements in the reform period. $\mathrm{He}$ confirmed continuing support for China's reforms as a way of further strengthening China's socialist market economy (Tisdell 2008).

Across China, there were over 400 million fewer people living in extreme poverty in 2001 than 20 years previously. Between 1981 and 2001, the proportion of China's population living in poverty fell from $53 \%$ to just $8 \%$ (Ravallion \& Chen 2004). However, this progress was not always smooth. Significantly, there was a rapid decline in poverty in the first half of the 1980s, when around 200 million people were lifted out of extreme poverty, but the rate of change was not continual thereafter, with periods of some set-backs for China's poor such as in the late 1980s and late 1990s (Ravallion \& Chen 2004). Nevertheless, the lifting of more than 400 million out of poverty has been no mean achievement given the size of China's population. China has been held up by the United Nations Development Program (UNDP 2015) as a country to emulate when it comes to poverty reduction. At the end of 2014, China had 70 million people in the countryside living below the nation's poverty line of 2300 yuan (about US\$354) in annual income (Xinhua News 2016a). China aims to eliminate poverty by 2020 when its 13th 5-Year Plan is completed (Xinhua News 2016a).

\section{Development challenges in China}

There remain, however, serious issues of wealth inequality, endemic corruption and moral misconduct. The 'One 
Thousand Questionnaire' survey conducted by the People's Tribune in 2009 presented 10 societal challenges for China in the next 10 years and asked respondents to rank them in order of perceived severity (Zhao 2014). ${ }^{8}$ Among the top five, the first societal challenge selected by $82.3 \%$ respondents was 'Corruption levels exceed the limits people can bear'. The second social challenge identified by $80.6 \%$ of respondents was 'The gap between rich and poor widens, unfair distribution intensifies social conflicts'. The third societal challenge was the 'Conflict between grassroots cadres and the general masses', a response chosen by $82.3 \%$ of respondents. The fourth societal challenge was "The contradiction between high house prices and low income', selected by $82.3 \%$ respondents. And the fifth societal challenge was 'Credibility crisis, moral misconduct', identified by $82.3 \%$ of respondents (Zhao 2014).

It is clear that in the wake of its phenomenal economic rise, China has to face a plethora of social and political problems not least of which is the ever-widening rich-poor gap. An International Monetary Fund (IMF) working paper on income inequality in China has pointed out that income inequality - as measured by the Gini coefficient for pre-tax market income exhibited an increasing trend from 0.28 in 1980 to 0.44 in 2000 and 0.52 by 2013 (Cevik \& Correa-Caro 2015). There was also a significant within-China variation in income inequality at the regional level. This widening in the gap between rich and poor shows China's transition from a relatively egalitarian society to one of the most unequal countries in the world (Cevik \& Correa-Caro 2015). This corroborates a separate study done in 2014 (Xie \& Zhou 2014).

Between 2010 and 2012, the average net worth of a Chinese household rose $17 \%$ to $\$ 71000$ but inequality continues to be a serious and growing problem (Kaiman 2014). It was reported that, in a 2012 survey by Peking University, the poorest $25 \%$ of Chinese citizens owned only $1 \%$ of the country's wealth while $30 \%$ of the country's wealth is concentrated in the hands of $1 \%$ of its citizens (Kaiman 2014). In many ways, China is joining the rest of the world where inequalities are growing, with the richest $10 \%$ owning $86 \%$ of all wealth and the bottom half owning less than $1 \%$ (Kaiman 2014).

Indicative of the growing impatience and lack of tolerance for economic and social injustices among younger generations of migrant labourers in the cities is the rise in the number of protests and demonstrations in China in recent years. Public protests since 2000 have been sparked by labour disputes, land acquisitions, forced demolitions, pollution, traffic accidents and incidents involving ethnic groups, a major report found. The Annual Report on China's Rule of Law No 12 (2014) is based on research into 871 mass incidents involving more than 2.2 million people that occurred between 1 Jan 2000, and 30 Sept 2013 (Hou 2014).

The growing incidence of social unrest is partly related to the rapid urbanisation that has taken place in China. Its

8.The survey was carried out by the People's Tribune (2009) in the context of societywide discussions about China's rise following news of its economy having becomthe discussions about China's rise following news of its economy having become the second largest in the world. Respondents were asked what challenges confronted China in its ascent as a global economic power. After having identified the top 20 challenges, a second set of respondents (1000 of them) were asked to rank them. The author has selected the top five challenges identified. urbanisation rate is one of the fastest in the world. In 1978, when it started opening up, less than $20 \%$ of the population lived in urban areas. China's urbanisation rate is expected to hit $60 \%$ by 2018 (Jourdan 2013). How cities will cope with the population influx in urban areas will continue to be a serious challenge for the government. In the past 30 years, China's urban population has jumped to more than 700 million from less than 200 million, a dramatic shift that has sometimes triggered violent clashes over land use, as well as water shortages, pollution and other problems (Jourdan 2013; Tong \& Lei 2010).

In addition, China has a population that is fast ageing. Recent estimates indicate that at the end of 2015 , almost $16 \%$ of the population (amounting to 222 million) is over 60 years of age (Xinhua News 2016b).

\section{Growth in faith-based organisations}

In the face of such serious challenges, some of which are economic while many are social and political, the Chinese government has acknowledged the need to harness the support of civil society in achieving its development goals. This would include FBOs. However, compared to secular organisations, their engagement in social development has been much more restricted.

It was only after 2003 that the SARA publicly encouraged the Chinese religious sector to engage in providing social services. In response, the China Christian Council, for instance, established its own Social Service Department in 2003 that began to operate developmental projects similar to those of the Amity Foundation. ${ }^{9}$ In 2012, together with five other ministries, SARA issued a key document (called the 'Opinions' $)^{10}$ to further facilitate the involvement of religions in social service. This has stimulated some growth in the number of faith-based foundations (FBFs). It should be noted that in China, organisations that are officially registered as 'public foundations' (whether secular or religious) are legally allowed to do public fundraising. Those registered as 'private foundations' are not allowed to engage in public fundraising. ${ }^{11}$ Registration fees for foundations are prohibitively high compared to the registration fees for regular FBOs.

It is therefore not surprising that the number of FBFs has remained small. The China Foundation Centre in Beijing noted that there were only five at the end of the twentieth century. The sector saw some growth after 2003. There were altogether $15 \mathrm{FBF}$ registered in the first decade of the twentyfirst century and between 2010 and 2011, seven more were registered bringing the total to $22 \mathrm{FBFs}$. The numbers are strikingly small for a country the size of China but we can

9.The Amity Foundation, a Christian-initiated NGO, was established in 1985 and led by Bishop K. H. Ting. It engaged in poverty reduction work as well as bible-printing from the very start. This was considered pioneering at the time and provided a platform for churches to be involved in society. See www.Amityfoundation.org.

10.See the 'Preface' written by Z. Qiu in Carino (2014). The 'Opinions' have also been referred to as 'Views on Encouraging Religious Groups to Carry Out Charitable Activities and the Regulation of the Same' (China Zentrum 2012).

11.Private foundations are generally funded by a major gift from a wealthy individual or corporation. The original funds required for setting up a private foundation (RMB2 million) is lower than for setting up a public foundation (RMB4 million) (see Feng 2013). 
expect more FBOs, including FBFs, to emerge in Chinese society in the future and to play a role in social service development.

\section{Areas where FBOs are concentrated}

There are certain areas where FBOs tend to be concentrated. In 2014, out of 878 private orphanages in the whole country for instance, more than 649 , or $74 \%$ of these have been set up by either Christian or Buddhist groups (Ministry of Civil Affairs (MCA) 2014). In recent years, more FBOs have set up nursing homes and elder care centres throughout the country. In 2014, there were altogether 471 FBOs in China including foundations, senior care centres and nursing homes, kindergartens, charity hospitals and clinics (MCA 2015).$^{12}$ Of these, 250 were registered while 221 remained unregistered. Among those with a Christian background, there were 202 registered and 26 that were not (MCA 2015). These figures only show part of the picture.

There are many FBOs including orphanages that are registered as enterprises or are simply not registered at all. Those registered as enterprises have to pay taxes even though they are non-profits doing charity work. It is still difficult for FBOs to register at government departments, as religious affairs are usually considered politically sensitive and many of the policies and regulations concerning religious organisations involved in social services remain unclear. Much is then left to the interpretation of local government officials, whose willingness to help may vary considerably depending on a wide range of factors including the history of local church-state relations, and the ideological and political stance of local officials. On the other hand, some FBOs prefer not to register so as to avoid having their activities monitored by the authorities.

FBOs without legal status encounter difficulties if they want to enlarge their scale of operation. Neither can they obtain subsidies from the local government or engage in public fundraising. For orphanages that are not registered, the problem becomes even worse. As the abandoned children ${ }^{13}$ have no birth certificates, they do not have legal identities. They cannot be legally adopted and experience great difficulties in acquiring a residence certificate without which they cannot avail of government subsidies or support for education and healthcare.

In general, most FBOs tend to operate on a very small scale and are constantly in need of funding support and human power. Having only limited resources, they tend to depend on volunteers or part-time rather than fulltime employees, which means that their services are not always stable or sustainable. This is especially so with social services that requires increasing levels of professionalism including in

12. Names of church-run hospitals in China include: Zhoukou Gospel Hospital in Henan: Linqu Amity Hospital in Shandong: Luzhou Gospel Hospital in Sichuan; Huaian Gospel Outpatient Clinic. There Catholic Church in different provinces.

13.In China, partly because of the one-child policy, impoverished villagers tend to abandon babies born with defects near orphanages run by FBOs in the hope that they can receive better care. These children are, by definition, not 'orphans' since one or both parents may still be alive. healthcare and services for the elderly and people with disabilities. A growing part of Amity's work in these areas consists of organising training workshops for capacity building for smaller or less experienced FBOs (Amity Foundation 2015).

\section{Role of FBOs: Service delivery or change?}

FBOs have been providing much needed help to the poor and vulnerable. As noted earlier, statistics from the MCA indicate that $74 \%$ of orphanages in China are operated by organisations with a religious background (2014). Catholic and Protestant organisations have also been involved in HIV prevention work, providing much needed awareness-raising in communities and support for people living with HIV. In their work with vulnerable peoples, FBOs do not just deliver services, but they work at changing mindsets and attitudes. People living with HIV, disabilities and mental illness have always suffered humiliations and stigma from the public, including from their own families. Through the work of dedicated staff in FBOs, some of this is beginning to change.

China's pragmatic approach to economic reforms has been to hold limited or controlled experimentations, initiating many pilot programmes or creating special economic zones to determine the right policies. Successful 'models' are then replicated on a larger scale from the county or municipal levels upwards to provincial levels. Eventually, if such projects are successful, they become part of policies formulated at the national level. Thus, in the Chinese context, 'model projects' constitute a practical form of 'advocacy' by civil society organisations (CSOs). Rather than posing direct challenges to the state or making open critiques, many NGOs/FBOs prefer to present viable, workable solutions to social problems. By proving the efficacy and impact of a 'development model' at the micro- or local levels, they can persuade and convince local governments to adopt these models or approaches that are then scaled up. An illustration of this approach can be gleaned from Amity's work on HIV prevention.

Amity started to pay attention to the HIV issue in the 1990s. A 3-year AIDS Prevention Education Program was started in Yunnan in 1996 (Zhang 2004). The programme offered training courses for HIV educators at the county, township and village levels. HIV education materials such as pamphlets, textbooks and posters were distributed, and HIV prevention knowledge was transmitted through mass media including radio, television, films, videos, school blackboards and publicly posted slogans. House-to-house visits were made to ensure that people, both infected and uninfected, were educated. The programme won much praise from local and foreign experts as well as from the people and the local governments (Zhang 2004). In the final evaluation of the programme, which was successfully completed at the end of 1998, the following conclusions were made: The programme 
and Amity's participation in it not only benefited local villagers but had also mobilised government departments to invest more resources for the prevention of HIV (Zhang 2004). On the basis of the successful implementation of the 3-year AIDS Prevention Education Program, Amity started in 1999 a second 3-year programme of AIDS Prevention and Care and expanded to four counties of Menglian, Lincang, Fengqing and Chengjiang in Yunnan Province. While preventive education continued to be promoted, new elements of care were added to the programme. It included counselling to boost the confidence of HIV-positive people and to counsel family members to accept them. There was provision of medical check-ups, free food and treatment for HIV-positive people especially for those who were extremely poor (Zhang 2004). The scaling up of Amity's programme thus included gaining more government investment in it, expanding to more counties and adding new and important elements to the projects, all of which expanded their impact on local communities. To date, these public healthcare and HIV prevention drives have run training workshops for 16000 village doctors and 6900 township hospital workers in nine provinces in west China, helped establish hundreds of village clinics in poverty-stricken regions and launched prevention and treatment campaigns for diseases such as iodine deficiency disorder (IDD) and gynaecological diseases (Qiu 2015).

Over the last three decades, international NGOs (INGOs) and Chinese CSOs alike have been channels for transmitting 'modern concepts and approaches to development' through experimental or pioneering projects. This has accompanied a process of gradual devolution of government control and administration of basic social services to local NGOs and the private sector. To cite an example based on Amity Foundation's experience, the concept of 'participatory development' - which involves notions of self-reliance and democratisation at the grass roots level - has been promoted as part of project implementation. ${ }^{14}$ In practice, this has, for example, involved an insistence on farmer or stakeholder participation in the design, implementation and assessment of rural poverty alleviation projects. Local officials are required to attend workshops together with farm leaders to jointly prioritise project goals and targets. Project committees must have equal gender representation and financial contributions include those from farmers, government and Amity. ${ }^{15}$

This approach has fostered a stronger sense of project ownership among stakeholders and led to changes in attitudes among Amity's local government partners. They become more consultative and community-based in their approaches to local governance leading to improvements in levels of transparency and accountability at local government levels.

14.Discussions about the importance of the participatory approach in socia development can be found in International Fund for Agricultural Development (IFAD), 2001.

15.In the Amity Foundation Work Report delivered at the celebration of its 30th anniversary, it was stated that the foundation had raised RMB 2 billion from overseas and local partners for projects between 1985 and 2015, together with matching funds from local governments amounting to RMB 1 billion (see Qiu, 2015).
One example of such an impact has been at Woyun Administrative Village in Mianzhu County, Sichuan, where Amity delivered emergency relief after the massive earthquake of 2008. In 2013, an effort was made by Amity to assess the impact of its project in the reconstruction of more than 900 homes in Woyun Village that had been completed in 2009 (Carino 2013). One area of assessment was the extent to which the consultative approach in governance, which Amity had advocated, had been sustained. During the reconstruction of homes, Amity had organised the Woyun Village Reconstruction Committee that consisted of the village heads from all 16 natural villages in Woyun. To enable better representation and a gender balance, each village also had to elect a female representative to the committee, eventually raising membership to 32. Frequent consultations and village meetings were held to ensure that the reconstruction process had the full participation of all households. To assess whether the consultative process and participatory approach had been retained after the reconstruction project, Amity's 2013 survey asked the question whether respondents felt that village leaders listened to them more since the earthquake. Seventy per cent indicated that village leaders listened to them more after the earthquake, while $15 \%$ said it was the same as before, and only $8 \%$ said they were not listened to (Carino 2013). When asked if more meetings were now being held by the Village Committee to discuss common issues compared to the period before the earthquake, $62 \%$ said that there were now more meetings, while $16 \%$ said the number of meetings held were the same, and $11 \%$ felt that there were fewer meetings after the quake. A high number of blanks, representing $12 \%$ of those surveyed, were returned (Carino 2013). These responses are indicative that the reconstruction process in Woyun had led to some attitudinal changes towards governance by the local village committee even if these changes have not been institutionalised.

Amity's bottom-up, participatory approach has been challenging for officials accustomed to a top-down style of working. Commenting on the partnership with Amity, a local official, who had been in poverty alleviation work for 13 years, praised Amity's participatory approach. In 2000, Yu Wen Youyu, the then Director of the Poverty Alleviation Office of Jinzhong Prefecture in Shanxi, admitted that much of his previous efforts had failed, because of the top-down approach and the lack of consultation with villagers. When Amity organised a Participatory Rapid Appraisal (PRA) workshop, involving technical support staff, administrators, researchers and farmers, Yu Wen could not imagine how such a mixed group of people could be trained together. He changed his mind after the experience, acknowledging that 'Even the farmers who were illiterate raised good questions!' (Carino 2000).

\section{Role of faith-based organisations in development: Transformative values}

Project planning, monitoring and evaluation (or PME in NGO jargon) can be an effective form of interactive learning between FBO staff, local authorities and church leaders. So is the insistence on participatory planning and implementation. 
Human agency is important. It is the values and the peopleoriented approach of FBOs that make a difference. In China, scholars such as Xiangping Li and Dedong Wei who have studied FBOs have emphasised the importance of the normative in FBO contributions to sustainable development (Li 2014; Wei 2014). FBOs such as Amity Foundation and its Catholic counterpart, Jinde Charities, have pioneered in many areas that were considered difficult and taboo. In 1997, both organisations began work on HIV education and prevention when it was still a little known disease.

In an interview, Fr J.B. Zhang, the founder of Jinde Charities, recalled:

In 1997, when Beifang Jinde was founded, HIV-AIDS was not on the project list. Then, in 1998, three friends from Maryknoll advised me to include it. However, all our proposals for training and cooperation were turned down by administrative and healthcare institutions given the social sensitivity and taboo of HIV-AIDS. As HIV infection accelerated in recent years, our determination in this area has become so firm that we started the Light of Hope, a Chinese Catholic AIDS initiative, regardless of the skepticism. (Wei 2014)

Overcoming the stigma associated with diseases such as AIDS has been very challenging. However, it is precisely because working with marginalised groups has been a faithbased conviction that both organisations embarked on the projects.

Dedong Wei has observed that projects involving leprosy patients and disabled infants require much devotion and commitment. Many Catholic nuns spend their entire lives providing that service. After a visit to a care centre for people with disabilities run by Catholic nuns in Hebei, a monk from a Buddhist orphanage was impressed by what he observed as 'the upholding of God's love and the replacement of complete despair with the greatest mercy'. This magnificent compassion has much to do with religious faith. 'Religion casts love in the darkest and coldest corners' (Wei 2014).

\section{The impact of social engagement for faith-based organisations}

According to Li and Wei, Christians' social actions have helped remove prejudices about Christianity (Li 2014; Wei 2014). It is believed that:

by transforming stereotypes and removing, where applicable, prejudices and misconceptions, social service is a key and effective way of showing the value of religions in present day China. With a higher social status, churches can enjoy a less apprehensive, more welcoming and receptive general public. (Wei 2014)

Engagement in social services and other social actions have helped FBOs to become more active, visible and immersed in local communities. In Beijing, for instance, Ren Ai, a Buddhist organisation, has been delivering warm breakfasts to those rushing to work at subway stations or street corners every day of the year. In Nanjing, the Amity Bakery is becoming a brand name for quality products and a successful social enterprise that champions the rights of the mentally challenged to have access to gainful employment (Amity Foundation 2013).

The pioneering projects implemented by Amity over the last three decades have inspired other groups, including local governments to replicate them. Among these has been the training of local public healthcare workers (or 'village doctors') in very remote regions in Northwestern parts of China, accompanied by clinics, to provide basic healthcare for very poor communities. The training modules and clinics eventually became the projects of provincial level governments. In the southwest of China, Amity's efforts at reforestation in the late 1990s also became noticed and adopted at the provincial level. Many of these efforts have not been adequately documented and will require further field research to ascertain the impact they have made. It is quite unfortunate that Chinese NGOs and FBOs alike, including Amity, have been more focused on project implementation and have paid less attention to assessing the impact of these projects on communities and local officials. As FBOs move towards advocacy work rather than simply service delivery, one can expect that more documentation will be available to attest to the impact that FBOs have made in the field of 'development'.

\section{Raising funds domestically can help raise public awareness}

Until the turn of the century, much of the funding support for Chinese FBOs, especially among the Catholics and the Protestants, has come from overseas. Working with overseas partners provides new ideas, concepts and practices that are useful for Chinese FBOs. They do not have to re-invent the wheel in the development of their services and projects, and can very quickly adopt some of the best practices from abroad. With the downturn of economies in the west after the financial crisis of 2008, and China's concomitant economic rise, the amount of development aid directed towards China has shrunk dramatically. Many FBOs have begun to turn to domestic sources of funding for social service projects.

There are now not only many more billionaires and wealthy individuals but also a growing middle class in China. Research undertaken by Union Bank of Switzerland (UBS) and PricewaterhouseCoopers has revealed that a new billionaire was created almost every week in China in the first quarter of 2015 (Yan 2015b). There are now more than one million millionaires in China (Yan 2015a). The Hurun Research Institute, based in Shanghai, has estimated that China had over 230 billionaires in 2012 (Spero 2014).

Credit Suisse reported that China now has the largest middle class in the world with 109 million Chinese in this category compared to the 92 million in the United States (Credit Suisse 2015). They each have wealth of between $\$ 50 \quad 000$ and $\$ 500$ 000. Since 2000, twice as many Chinese as Americans have joined the middle class (Credit Suisse 2015). In China, this middle class is beginning to give to charitable causes. 
In 2012, the Hurun Research Institute published its ninth Hurun Philanthropy List identifying 100 Chinese donors who together contributed the equivalent of $\$ 1.6$ billion between January 2011 and March 2012 to support charitable causes including healthcare, education, poverty alleviation, disaster relief and social welfare, as well as culture and sports (Spero 2014). The channels for such contributions ranged from personal giving to foundations controlled by families or family-owned corporations. It should be noted that there has been only limited giving in more politically sensitive fields such as civil and human rights, environmental protection or other advocacy causes (Spero 2014).

Crowd-funding has become quite common and popular especially among the young. This is providing new opportunities for CSOs to raise local funds and to reach a much broader base in Chinese society that will continue to give to charitable and developmental causes. Domestic fundraising will also provide more opportunities for raising levels of public education and awareness that will reduce discrimination against the disabled, the mentally challenged and the elderly.

Through domestic fundraising efforts FBFs are gaining public visibility, respect, appreciation and support. In the last 5 years, through multimedia channels, the Amity Foundation and Jinde Charities have attracted increasing public support (Amity Foundation 2014). Amity has its annual Water Day Marathon in Nanjing and in Hong Kong to raise funds and consciousness about the water crisis and the need for environmental protection. Jinde Charities has its successful annual fundraising marathon in Beijing that features the unique participation of Catholic nuns who run wearing their habits. These are considered breakthroughs in changing perceptions of the religious sector.

The formation of networks of social workers and NGOs engaged in the same work will help to improve levels of professionalisation. New ideas and best practices can be effectively shared at conferences and seminars at the domestic and international levels. In recent years, for instance, Amity has made an impact on public perceptions of autism, care for the elderly and respect for the rights and dignity of vulnerable groups that include the mentally challenged.

While the performances of NGOs and FBOs in China have gained in credibility and public support, not all have been successful in this respect. The sector's public credibility suffered from a series of scandals in 2011 (Deng, Lu \& Huang 2015). The Meimei Guo incident which highlighted the luxurious lifestyle of a young woman with claimed links to China's Red Cross raised public distrust of Chinese NGOs. This was followed by accusations of misuse of charity funds by the Soong Ching Ling Foundation which had invested in real estate using donations that had been publicly raised. This credibility crisis impacted both grassroots organisations and the nationally prominent government-organised NGOs (GONGOs). Public critique on the lack of transparency, especially of the more established NGOs, affected their credibility and caused a dip in public donations. On the whole, these scandals generated a negative environment for China's civil society (Deng et al. 2015).

A survey conducted by the China Charity Information Center revealed that only $8 \%$ of respondents were satisfied with the level of transparency among Chinese NGOs, while $92 \%$ were dissatisfied (Deng et al. 2015).

\section{Conclusion}

Chinese FBOs tend to challenge the development agenda through their practices rather than through direct criticism or confrontation with the government. In this respect, there remain many grey areas for experimentation and innovation in social development practices despite political constraints. NGOs and FBOs have been tolerated and even welcomed by the Chinese government even as those overtly engaged in human rights work meet constant obstacles and censure. Amity Foundation has tried to work within the political boundaries, quietly promoting and creating 'space' for 'alternative' development strategies. In the present Chinese context, Amity's collaboration with the state sector, particularly at the grassroots level, provides opportunities to introduce new approaches and attitudes towards development. Amity's contribution includes its insistence on participatory management, gender equality, leadership development and ecological sustainability. Successful projects can become models for replication, have a multiplier effect and eventually impact policy formulation.

From the beginning, Amity has articulated the need to raise democratic consciousness and encourage participatory management. For Amity, education in democratic citizenship is part of development work, and project management is a learning process towards community-based development and participatory government.

Amity's present engagement with churches (as well as other religions), providing capacity building for church-run projects, will enable churches to become more fully immersed in social development work. This can transform society's understanding of Christianity as well as deepen Chinese Christian understanding of the gospel message. In church-run nursing homes for seniors, Christian staff and volunteers have made a mark in providing loving, tender care and spiritual nurture. They may not be the most professionally run institutions, but they are gaining a reputation for the love they convey and the self-sacrificing services they provide (Liu 2014). All these run counter to the prevailing materialism of a rising, affluent society and it is something that cannot be codified or quantified in national development plans.

There are still huge challenges linked to poverty and social marginalisation in China. At least 70 million people are living below the poverty level of 2300 yuan (US\$376) per capita per annum (Luo and Xu 2015). Some officials have claimed that every month, about 1 million people are being 
lifted out of poverty in China and the government's current target is to 'eliminate poverty' by 2020, 10 years ahead of the SDGs 2030 (Xinhua News 2016a). Even if this is attained, the disabled and elderly will still remain among the most disadvantaged in Chinese society. According to the UNDP (2008), there are around 83 million people in China with some form of disability. Unless marked improvements are made in the education, training and employment for the disabled and in removing discrimination and stigma against them, they will still remain the poorest in society. In this context, FBOs like Amity can play an important role in bringing about change.

\section{Acknowledgements Competing interests}

The author declares that she has no financial or personal relationships which may have inappropriately influenced her in writing this article.

\section{References}

Amity Foundation, 2013, US Ambassador Gary Lock visits Amity Bakery, Amity Outlook 4, April-June.

Amity Foundation, 2014, Annual Report, Amity Foundation, Nanjing, p. 8.

Amity Foundation, 2015, Celebration ceremony of Amity Foundation's 30th Anniversary: Work report, 6 November, Amity Foundation, Nanjing.

Ashiwa, Y. \& Wank, D.L., (eds.), 2009, Making religion, making the state, Stanford University Press, Stanford, CA.

Carino, T.C., 2000, 'Big push for participatory development', Amity Newsletter $52(1), 1-3$.

Carino, T.C., 2013, 'Post-disaster rehabilitation and community building: The experience of Woyun Village post-Sichuan earthquake 2008', Unpublished Research Report for Amity Foundation, Nanjing.

Carino, T.C., (ed.), 2014, Christianity and social development in China, Amity Foundation, Hong Kong.

Cevik, S. \& Correa-Caro, C., 2015, Growing (Un)equal: Fiscal policy and income inequality in China and BRIC, IMF Working Paper wp/15/68, IMF Fiscal Affairs Department, viewed 9 May 2016, from https://www.imf.org/external/pubs/ft/ wp/2015/wp1568.pdf

China Zentrum, 2012, 'News update on religion and church in China', Religions \& Christianity in Today's China II(3), 3-23.

Credit Suisse, 2015, Global middle class net worth doubled since 2000 to USD 80.7 trillion, $32 \%$ of global wealth, Media Release on the Global Wealth Report on 13 October 2015 by Credit Suisse Research Institute in Zurich viewed 29 October 2015, from https://www.credit-suisse.com/media/assets/corporate/docs/aboutus/media/media-release/2015/10/gwr-2015-global-press-release.pdf

Deng, G., Lu, S. \& Huang, C., 2015, 'Transparency of grassroots human service organizations in China: Does transparency affect donation and grants?' Unpublished Research Report No. 19, Huamin Research Center, Beijing.

Ebenstein, A., 2008, 'Water pollution and digestive cancers in China', viewed 18 August 2016, from http://paa2009.princeton.edu/papers/91541

Economist, 2011, 'China's economy and the WTO: All change', viewed 16 May 2016 from http://www.economist.com/node/21541448

Feng, X., 2013, China's charitable foundations: Development and policy-related issues, Working Paper No. 485, Stanford University Center for International Development, viewed 16 August 2016, from http://scid.stanford.edu/sites/default/files/ publications/485wp_0.pdf

Hou, L., 2014, 'Report identifies sources of mass protests', China Daily, 9 April, viewed 17 May 2016, from http://www.chinadaily.com.cn/china/2014-04/09/ content_17415767.htm

International Fund for Agricultural Development (IFAD), 2001, Participatory approaches for an impact-oriented project cycle, IFAD, Rome.

Jourdan, A., 2013, 'China's urbanisation rate to hit 60 percent by 2018', Financial Markets, Reuters, 26 December, viewed 18 May 2016, from http://www.reuters. com/article/china-urbanisation-idUSL3NOK607G20131227

Kaiman, J., 2014, 'China gets richer but more unequal', The Guardian, 28 July, viewed 30 July 2014, from http://www.theguardian.com/world/2014/jul/28/china-moreunequal-richer

$\mathrm{Li}, \mathrm{X}$., 2014, 'Distinctions between religious philanthropy and public charity: From social assistance to social construction', in T.C. Carino (ed.), Christianity and social development in China, pp. 139-150, Amity Foundation, Hong Kong.
Liu, P., 2005, 'Changing Chinese attitudes toward religion and culture: A comparative perspective', Unpublished paper presented at a seminar on religion and cultural change in China organised by Center for Northeast Asian Policy Studies, Brookings Institution, Washington DC. February 1, 2005, viewed 16 May 2016, from http:// Institution, Washington DC. February 1, 2005, viewed $16 \mathrm{M}$
www.brookings.edu/fp/cnaps/events/liupeng20050201.pdf

Liu, Y., 2014, 'Love and faith: An empirical study on the current situation of Christian charity in Jiangsu', in T.C. Carino (ed.), Christianity and social development in China, pp. 251-270, Amity Foundation, Hong Kong.

Luo, W. \& Xu, W., 2015, 'Country's poorest to get helping hand', China Daily, 30 October 2015, p.2.

Ministry of Civil Affairs (MCA), People's Republic of China, 2014, 'Notes on information concerning homes run by religious organisations for orphans and abandoned babies, viewed 23 October 2015, from http://www.mca.gov.cn/article/zwgk/ jd/201405/20140500631722.shtm

Ministry of Civil Affairs (MCA), People's Republic of China, 2015, '2014 statistics on social services', viewed 23 October 2015, from http://www.mca.gov.cn/article/sj/ tjgb/201506/201506008324399.shtml

Ocampo, C., 2014, 'Christian response to people-oriented development', in T.C. Carino, (ed.), Christianity and social development in China, pp. 179-194, Amity Foundation, Hong Kong.

Panitchpakdi, S. \& Clifford, M., 2002, China and the WTO: Changing China, changing world trade, John Wiley and Sons, Singapore.

People's Tribune, 2009, 'Report on the survey regarding the ten biggest challenges in the next ten years' (In Chinese), viewed 15 May 2016, from http://paper.people. com.cn/rmlt/html/2009-12/21/content_427048.htm

Qiu, Z., 2015, 'The 30th Anniversary celebration of the Amity Foundation: Work report', delivered in Nanjing, 6 November 2015, Amity Foundation, Nanjing.

Ravallion, M. \& Chen, S., (eds.), 2004, Fighting poverty. Findings and lessons from China's success, World Bank Research Report, viewed 18 May 2016, from http:// go.worldbank.org/QXOQI9MP30

Spero, J.E., 2014, Charity and philanthropy in Russia, China, India and Brazil, The Foundation Center, New York.

Tisdell, C., 2008, Thirty years of economic reform and openness in China: Retrospect and prospect, Working Paper No. 51, Economic theory Applications and Issues, School of Economics, University of Queensland, viewed 20 May 2016, from http://www.uq.edu.au/rsmg/docs/ClemWPapers/ETA/WP\%2051.pdf

Tong, Y. \& Lei, S., 2010, 'Large-scale mass incidents and government responses in China', International Journal of China Studies 1(2), 487-508.

UNDP, 2008, Access for all: Basic public services benefitting 1.3 billion people, in China Human Development Report, 2007/08, compiled by United Nations Development Program, Beijing November 2008, viewed 15 December 2012, from http://www. undp.org.cn/downloads/nhdr2008/NHDR2008_en.pdf

UNDP, 2015, China's success on Millennium Development Goals provides an example for others to follow for the post-2015 development agenda, 17 February, viewed 20 August 2016, from http://www.undp.org/content/u/ undp/en/home/sdgoverview/

Union of Catholic Asian News (UCAN), 2012, 'State launches religious charity campaign: Faith groups urged to provide standardised support', 18 September.

Vogel, E.F., 2011, Deng Xiaoping and the transformation of China, Harvard University Press, Cambridge.

Wang, T., 2014, 'The Catholic social service centre of Xi'an diocese: Stages in development', in T. C. Carino (ed.), Christianity and social development in China, pp. 271-282, Amity Foundation, Hong Kong.

Wei, D., 2014, 'Subjective consciousness, the core driving force of religious charity: A case study of Jinde charities', in T.C. Carino (ed.), Christianity and social development in China, pp. 83-94, Amity Foundation, Hong Kong.

Wickeri, P.L., 2007, Reconstructing Christianity in China: K. H. Ting and the Chinese church, Orbis Books, Maryknoll, NY.

Wickeri, P.L., 2010, 'Charity service and social development: The response of religions and the experience of the Amity Foundation', Unpublished paper delivered at the consultation on religion and social development during the 25th anniversary celebration of Amity in Nanjing.

World Bank, 2016, Overview of country report on China, viewed 8 May 2016, from http://www.worldbank.org/en/country/china/overview

World Commission on Environment and Development (WCED), 1987, Our common future, from one earth to one world, Chapter two: Towards sustainable development, Oxford University Press, Oxford, viewed 14 August 2016, from http://www.un-documents.net/our-common-future.pdf

Xie, Y. \& Zhou, X., 2014, 'Income inequality in today's China', Proceedings of the National Association of Science USA, viewed 9 May 2016, from http://pnas.org/ content/111/19/6928.full.pdf

Xinhua News, 2016a, 'China introduces poverty delisting policy', 29 April, viewed 8 May 2016, from www.chinadailyasia.com/nation/2016-04/29/content_15425072.html

Xinhua News, 2016b, 'Sixteen percent of China's population over 60', 4 May, viewed 17 May 2016, from http://www.chinadailyasia.com/nation/2016-05/04/ content_15426951.html

Yan, S., 2015a, 'China has more than 1 million millionaires', 27 May, CNN Money, Hong Kong, viewed 19 May 2016, from http://money.cnn.com/2015/05/27/luxury/ china-million-millionaires/

Yan, S., 2015b, 'China has a bigger middle class than America', 14 October, CNN Money, Hong Kong, viewed 19 May 2016, from http://money.cnn.com/2015/10/14/news/ economy/china-middle-class-growing/ 
Zhang, L., 2004, 'AIDS epidemic threatens China: Amity's response', Unpublished speech delivered at a conference organised by the Churches Together in Britain and Ireland (CTBI) in London in May, 2004, Amity Foundation, Nanjing.

Zhao, Z., 2014, The state of social entrepreneurship in China, SEFORIS country report $\mathrm{NPI}$, Beijing, viewed 14 August 2016, from http://www.seforis.eu/upload/reports/ Country_Report_China.pdf
Zhuo, X., 2014, 'Relationship between religion and state in the People's Republic of China', in Religions and Christianity in today's China, vol. IV, No. 1, pp. 16-24, China', in Religions and Christianity in today's China, vol.
viewed 11 December 2014 from www.china-zentrum.de

Zuo, L. \& Bai, Y., 2012, 'New regulations open the door for religious charities', Caijing Magazine, 27 March, viewed 5 October 2012, from http://english.caijing.com. $\mathrm{cn} / 2012-03-27 / 111778619 . \mathrm{html}$ 